\title{
Direct Seeded Rice: Strategies to Improve Crop Resilience and Food Security under Adverse Climatic Conditions
}

\author{
Raj K. Jat, Vijay S. Meena *(D), Manish Kumar, Vijay S. Jakkula, Illathur R. Reddy and Avinash C. Pandey \\ CIMMYT-Borlaug Institute for South Asia (BISA), Pusa, Samastipur 848125, Bihar, India; r.jat@cgiar.org (R.K.J.); \\ manish.kumar@cgiar.org (M.K.); v.jakkula@cgiar.org (V.S.J.); r.illathur@cgiar.org (I.R.R.); \\ a.pandey@cgiar.org (A.C.P.) \\ * Correspondence: v.meena@cgiar.org
}

Citation: Jat, R.K.; Meena, V.S.; Kumar, M.; Jakkula, V.S.; Reddy, I.R.; Pandey, A.C. Direct Seeded Rice: Strategies to Improve Crop Resilience and Food Security under Adverse Climatic Conditions. Land 2022, 11, 382. https://doi.org/10.3390/ land11030382

Academic Editor: Hossein Azadi

Received: 4 January 2022

Accepted: 21 February 2022

Published: 4 March 2022

Publisher's Note: MDPI stays neutral with regard to jurisdictional claims in published maps and institutional affiliations.

Copyright: (C) 2022 by the authors. Licensee MDPI, Basel, Switzerland. This article is an open access article distributed under the terms and conditions of the Creative Commons Attribution (CC BY) license (https:// creativecommons.org/licenses/by/ $4.0 /)$.

\begin{abstract}
Direct seeded rice (DSR) systems have been considered a sustainable strategy for sustainable rice (Oryza sativa L.) production and resilience under adverse climatic conditions. Providing essential nutrition for more than $50 \%$ of the global population, there has been a significant decline in rice productivity due to climate change. The results suggest that an adoption of DSR options, without raising rice nursery, improved rice productivity and time saving. A rice field experiment in the kharif season of 2021 was examined to identify the best crop establishment method. A comparison study of the direct seeded rice crop establishment method and the mechanical transplanting of rice crop establishment method was investigated to improve rice productivity. The results show that significantly higher $(+10 \%)$ rice productivity was registered in the DSR option compared with mechanically transplanted rice. In this case, growth attributes, effective tillers $(+37 \%)$, panicle length $(+8 \%)$, the number of grains per panicle $(+21 \%)$, and 1000 -grain weight $(+2 \%)$ were significantly higher in the DSR option compared with mechanically transplanted rice. It was observed that, after the third extreme rainfall, $100 \%$ of the mechanically transplanted rice crop was lodged, compared with only $25 \%$ of the DSR option. Overall, the results suggest that an adoption of DSR options significantly improved rice productivity and rice resilience, while offering the additional benefit of advancing the seeding of succeeding crops by 15 days compared with the mechanically transplanted rice system. Our study suggests that the adoption of the DSR option would sustain food security and crop resilience under adverse climatic conditions.
\end{abstract}

Keywords: direct seeded rice; mechanization; adverse climatic condition; productivity

\section{Introduction}

In the recently released Global Hunger Index (GHI) 2021, India was placed 101st and 94th, among the 116 and 107 nations covered in the report, in 2020 and 2021, respectively (https: / / www.globalhungerindex.org, (accessed on 20 December 2021). Developing the farm-level adoption of climate-resilient production systems for rice (Oryza sativa L.) is crucial to empower farm families to sustain their household food security. Under rice-based cropping systems, $\sim 40 \%$ of area and $\sim 50 \%$ of production comes from the Indo-Gangetic Plains (IGP) of India [1,2]. Rice is a global primary food and is cultivated over $162 \mathrm{M}$ ha, covering approximately $11 \%$ of global cultivable land that produces approximately $758 \mathrm{Tg}$ (million metric tons) of rice per annum [3]. In the eastern part of India, $18 \mathrm{M}$ ha of cultivable land is dominated by rice-based production systems which cover about $42 \%$ of the total area of national rice production systems [4]. Puddled transplanted rice-based production systems are high energy and cost intensive, and result in a less profitable production system $[5,6]$. In consequence, there is an imperative need to identify possible suitable crop establishment methods, specifically for rice production systems, to reduce the adverse impacts of climate change and increase productivity and profitability [6-8]. Direct seeded rice (DSR) systems have significant potential to reduce the environmental 
footprint and increase production [6,9]. Consequently, maintained productivity and sustained environmental quality could be achieved through improved production $[10,11]$. Nowadays, productivity has become stable due to present crop cultivars. In India, most of the farming community use long-duration rice varieties ( $>140$ days), which postpone the planting of succeeding winter crops (wheat, winter maize, lentil, chickpea, potato, mustard, linseed etc.). Alternative suitable winter crops are decisive and largely depend on the rice harvesting $[12,13]$. Puddled transplanted rice is an energy-intensive crop establishment method for rice and is known to degrade the soil system and negatively impact succeeding winter crops [14-16]. To overwhelm the limitations of late seeding, alternative techniques must be adopted. DSR might be a suitable alternative to advance climate-resilient methods in an efficient manner [17-19].

The DSR option has the advantages of directed seeding in low residue pressure, using the zero-tillage and multi-crop planter, and in high residue pressure, with the Happy Seeder and Super Seeder. Furthermore, the DSR option has been known to sustain soil systems and increase productivity and profitability $[6,20]$. In addition, adoption of the DSR option advances seeding by 15 days $[15,17]$.

The above statistics highlight the urgent need for the recognition of a sustainable crop establishment method for rice production systems in the eastern IGP under adverse climatic conditions [6,9]. Thus, sustaining the rice-based production system through various management practices, such as direct seeding and the mechanical transplanting of rice, provides sustainable options to meet the global rice demand without deteriorating natural resources. Some fundamental questions and state-of-the-art methods remain unexplored, such as (i) the general importance of DSR in the context of mitigating climate change; (ii) how and where DSR may be a more efficient crop establishment method; (iii) the importance of direct seeding for sustainable rice production systems; and (iv) how (i-iii) may lead to a better understanding of sustainable food security under adverse climatic conditions. Based on the literature discussed above and the questions raised here, we hypothesized that the DSR option could be a crucial factor in improving rice productivity and resilience. The goals of this investigation were to establish (i) a comparison study of puddled transplanting and DSR; (ii) the overall crop performance, including productivity and lodging, in both crop establishment methods; and (iii) lessons from adverse weather conditions where the DSR method was executed. The results presented would assist policymakers, researchers, and producers to better utilize the available natural resources. The outcome of the present investigation can efficiently counteract these problems by managing food production systems; restoring the degraded soil system; meeting the UNSDGs of zero hunger, climate action, and life on land; and can also play a greater role in achieving the 'Sustainable Development Goals' of the 2030 Agenda of the U.N.

\section{Materials and Methods}

\subsection{Experimental Site Details}

A large-plot field experiment was conducted during the kharif season of 2021 at the research station of CIMMYT-BISA, Pusa (Samastipur-Bihar), in the subtropical, humid climatic conditions of the eastern Indo-Gangetic Plain (E-IGP) of India. The field experiment was divided into 20 replications of direct seeded rice and 10 replications of mechanically transplanted rice with the plot size $40 \times 50 \mathrm{~m}$ (2000 square meters). The experimental soil was clay loam in texture. The two crop establishment methods of direct seeded rice and mechanically transplanted rice, under rice-based cropping systems, were tested. The experimental plots were under sugarcane-based cropping systems for more than two decades before the establishment of the CIMMYT-BISA research station in 2011. The site of the field experiment is presented in Figure 1. 


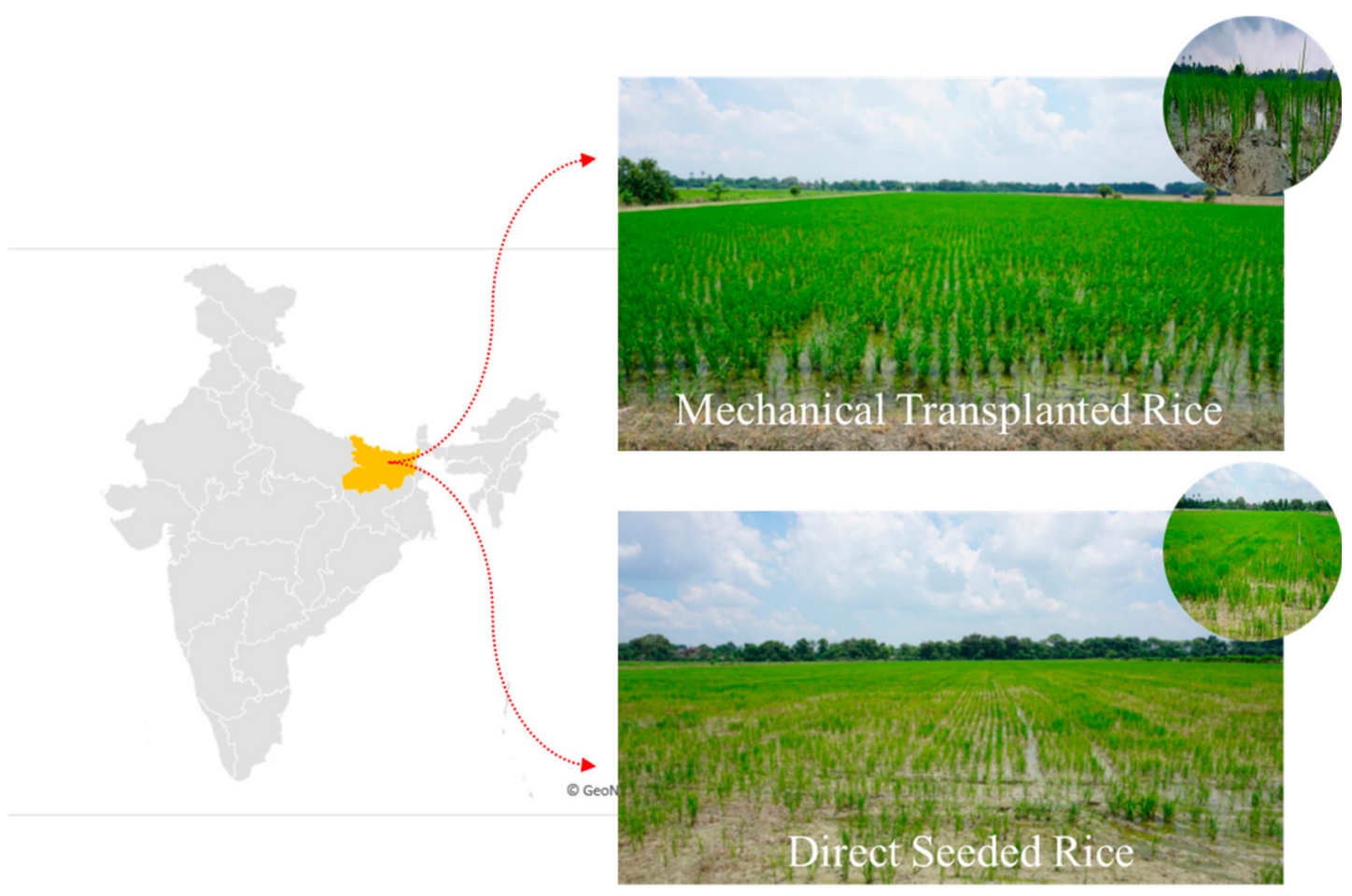

Figure 1. Experimental plot at the research station of the Borlaug Institute for South Asia (BISACIMMYT), Pusa, Samastipur (Bihar), India.

\subsection{Planting Methods}

The rice crop can be planted by different methods such as dry direct seeding, wet direct seeding, and transplanting (manual and mechanical). Each planting technique differs from the other [21]. Puddled transplanted rice is one of the most popular techniques used among the farmers of South Asia and tropical countries. Different crop establishment methods in rice are being used (Figure 2). DSR options \{(dry DSR by a Happy Seeder, a zero-tillage machine, a multi-crop planter, and a manual rice-wheat seeder), (wet DSR by a drum seeder), and (transplanting-mechanical transplanting by a six and eight row transplanter), and (manual transplanting by maintaining row spacing with the help of a rope)\}. For the present study, the two crop establishment methods of (i) direct seeded rice and (ii) mechanically transplanted rice were used.

\subsection{Crop Planting}

Under the DSR option, a seeding depth of 2 to $3 \mathrm{~cm}$ was maintained by using the depth control wheel of the Happy Seeder. The rice crop hybrid variety, Arize 6129 Gold, was dry seeded on 11 June 2021 by the Happy Seeder (seed-cum-fertilizer system) with a row geometry $(20 \mathrm{~cm})$ control system with a $25 \mathrm{~kg} / \mathrm{ha} \mathrm{seed} \mathrm{rate.}$

Meanwhile, the mechanically transplanted rice method used an eight-row mechanical transplanter. Sixteen-day-old young rice (Arize 6129 Gold) seedlings were transplanted. For mechanical transplanting, a mat nursery was raised on 1 June with $25 \mathrm{~kg}$ of seed for $100 \mathrm{~m}^{2}$ (for $1 \mathrm{ha}$ ). Seedlings were transplanted on 16 June with control row geometry at $20 \mathrm{~cm}$.

\subsection{Climatic Conditions}

The climatic conditions are described as hot and humid in the summer and cold in the winter with an average yearly rainfall of $1344 \mathrm{~mm}, 70 \%$ of which is received during July to September. The annual rainfall of the cropping cycles varied from 787 to $2390 \mathrm{~mm}$. The mean monthly minimum $\left(7.0\right.$ to $\left.10.3^{\circ} \mathrm{C}\right)$ temperature occurred in January and the mean monthly maximum (33.5 to $38.5^{\circ} \mathrm{C}$ ) temperature occurred in May/June. The monthly mean pan evaporation for monsoon season is $3.4-4.5 \mathrm{~mm}$ and is $2.8-4.4 \mathrm{~mm}$ in the winter 
season. Climatic data, such as rainfall and minimum and maximum temperatures, were recorded at the research station by the Automatic Weather Station (AWS). The climatic scenario of the experimental site is presented in Figure 3.

\section{Different Planting Methods of Rice}
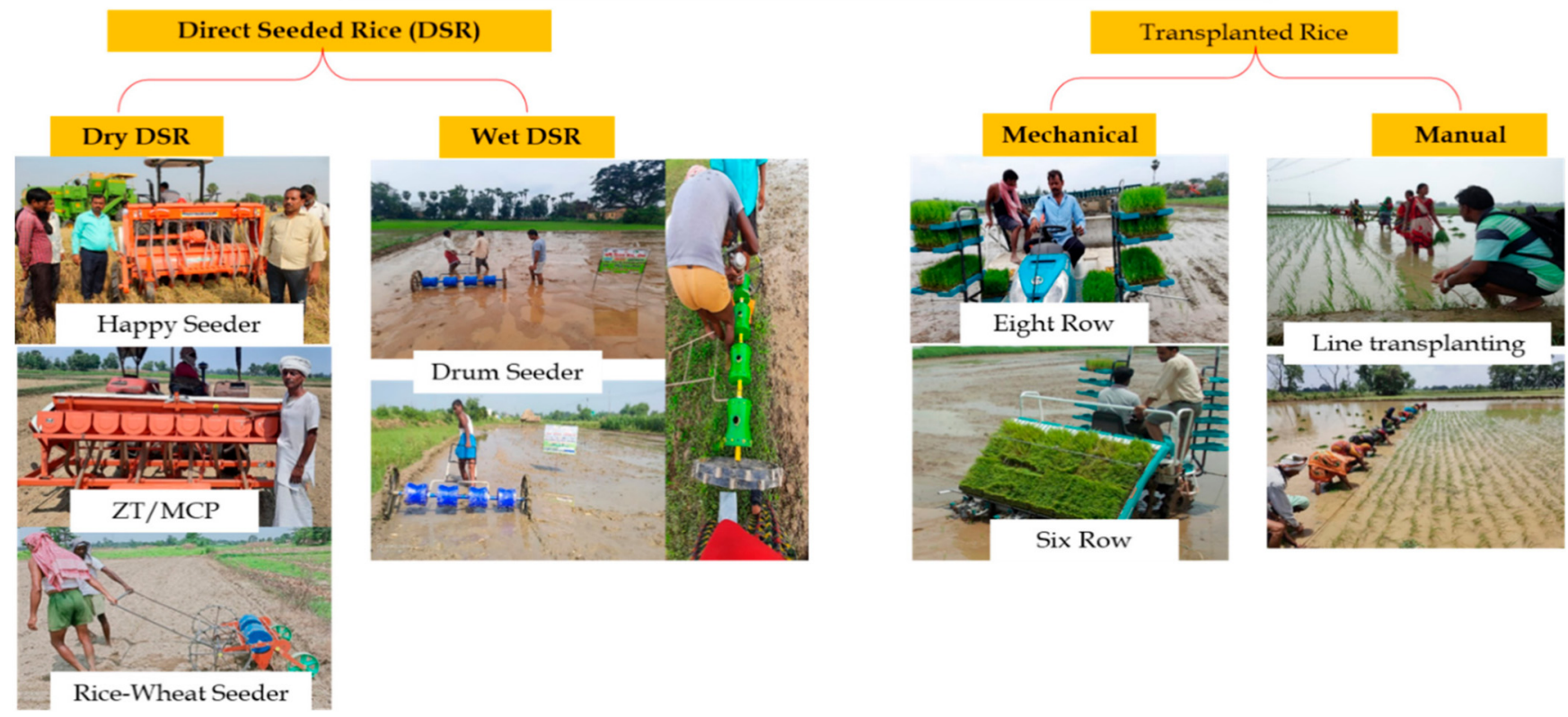

Figure 2. Different crop establishment methods of rice.

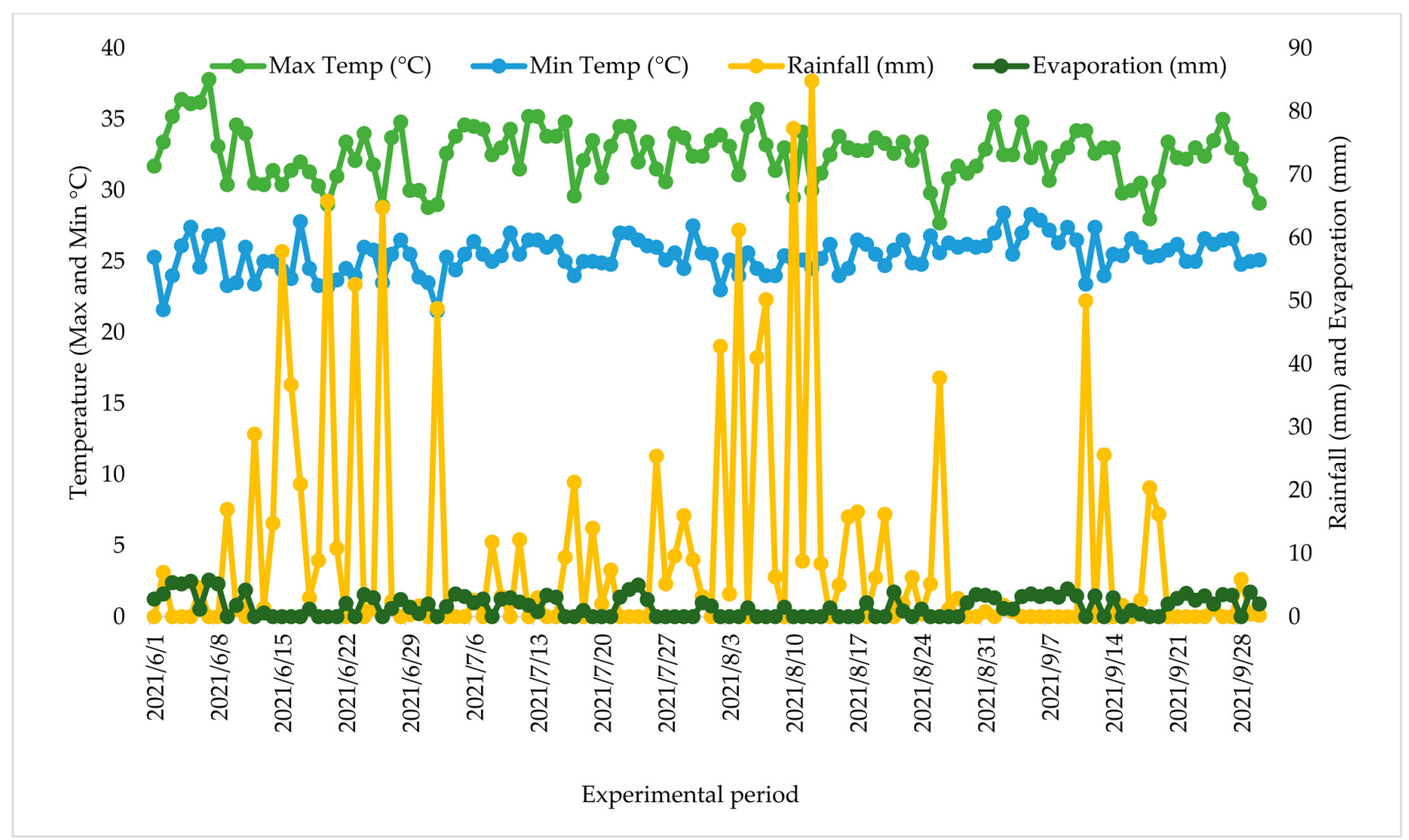

Figure 3. Climatic conditions during the kharif season of 2021: maximum and minimum temperatures, rainfall, and evaporation. 


\subsection{Nutrient, Weed and Water Management}

Diammonium phosphate (DAP) was applied as the basal dose (for $\mathrm{P}$ and $\mathrm{N}$ ) at $60 \mathrm{~kg} / \mathrm{ha}$. Meanwhile, nitrogen at $150 \mathrm{~kg} / \mathrm{ha}$ was applied in three equal doses. Similarly, $\mathrm{ZnSO}_{4}$ was also applied at $25 \mathrm{~kg} / \mathrm{ha}$ with the second split of nitrogen (Figure 4). Weed management is a major issue for rice crops, especially for the high productivity of the direct seeded rice. For the DSR, pre-plant herbicides glyphosate (systemic herbicide) at $10 \mathrm{~mL} / \mathrm{L}$ is mixed with $500 \mathrm{~L}$ water/ha, and 18-23 days after seeding Pyrazosulfuron (20 g a.i.) + Bispyribac-sodium (25 g a.i.) per ha was applied. Similarly, mechanically transplanted rice also used the same herbicide except for pre-plant herbicides (Figure 4). During the crop season, sufficient rains were received at critical stages of the rice. No external irrigation water was applied (Figure 3). At maturity, we recorded the grain yield of the rice (at 13\% moisture content) by harvesting each replication.

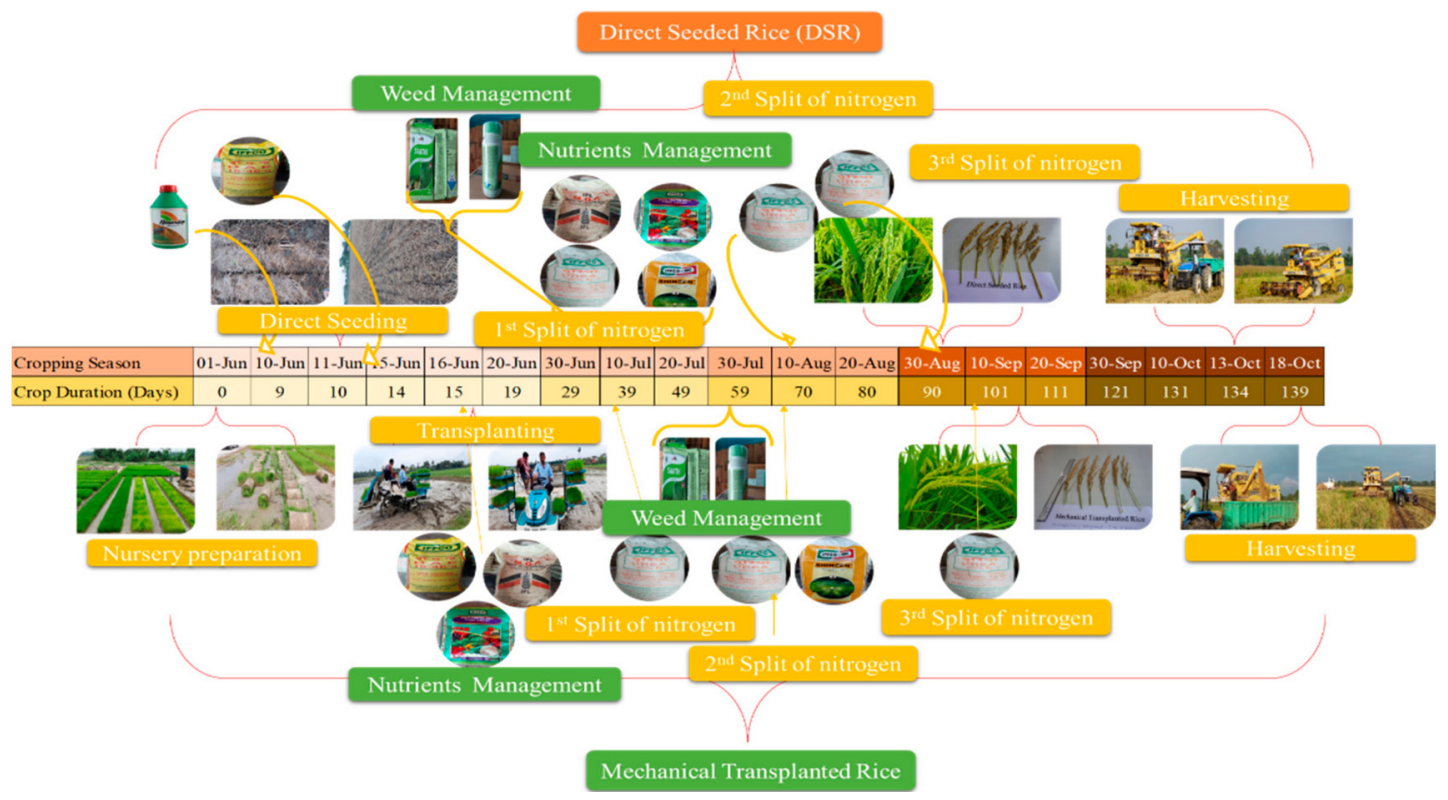

Figure 4. Different management practices under direct seeded and mechanically transplanted rice during the experiment (due to sufficient rains during the crop growth stages, no irrigation was provided to the crop).

\subsection{Statistical Analysis}

The data of rice growth, yield, and loading percentage were compared using the $t$-test for independent samples. The $p$-level reported is the standard, one-tailed $t$-test probability. Because of land availability, for the research trail for this study, the crop establishment methods' tested replications varied.

\section{Results}

\subsection{Plant Height and Effective Tillers}

The results show that an average plant height of $120 \mathrm{~cm}$ was recorded in both planting methods. No significant differences were observed due to the planting methods (Figure 5a and Table 1). Data showed that the effective tillers per square meter, significantly varied from 160 to 256 . It was observed that $\sim 37 \%$ higher effective tillers were registered under direct seeded rice compared with mechanical transplanted rice (Figure $5 b$ and Table 1).

\subsection{Length of Panicle and Number of Grains per Panicle}

Data showed that the panicle length significantly varied from 24.83 to $26.83 \mathrm{~cm}$. The significantly highest panicle length $(26.83 \mathrm{~cm})$ was registered in direct seeded rice and the lowest was registered with mechanically transplanted rice $(24.83 \mathrm{~cm})$. It was observed as $\sim 7.41 \%$ higher in direct seeded rice compared with mechanical transplanting 
(Figure $5 \mathrm{c}$ and Table 1). However, the number of grains per panicle also significantly varied from 200 to 253. It was, significantly, $21 \%$ higher in direct seeded rice compared with mechanical transplanted rice (Figure $5 \mathrm{~d}$ and Table 1 ).

\subsection{0-Grain Weight and Productivity}

The results show that the grain weight of 1000 grains varied from 23.31 to $23.74 \mathrm{~g}$ in both the direct seeded and mechanically transplanted rice. It was observed that, in the direct seeded rice, the 1000-grain weight was $\sim 2 \%$ higher than that of the mechanically transplanted rice. Meanwhile, it was observed that fewer differences were found between both crop establishment methods (Figure 6a and Table 1).

(a)

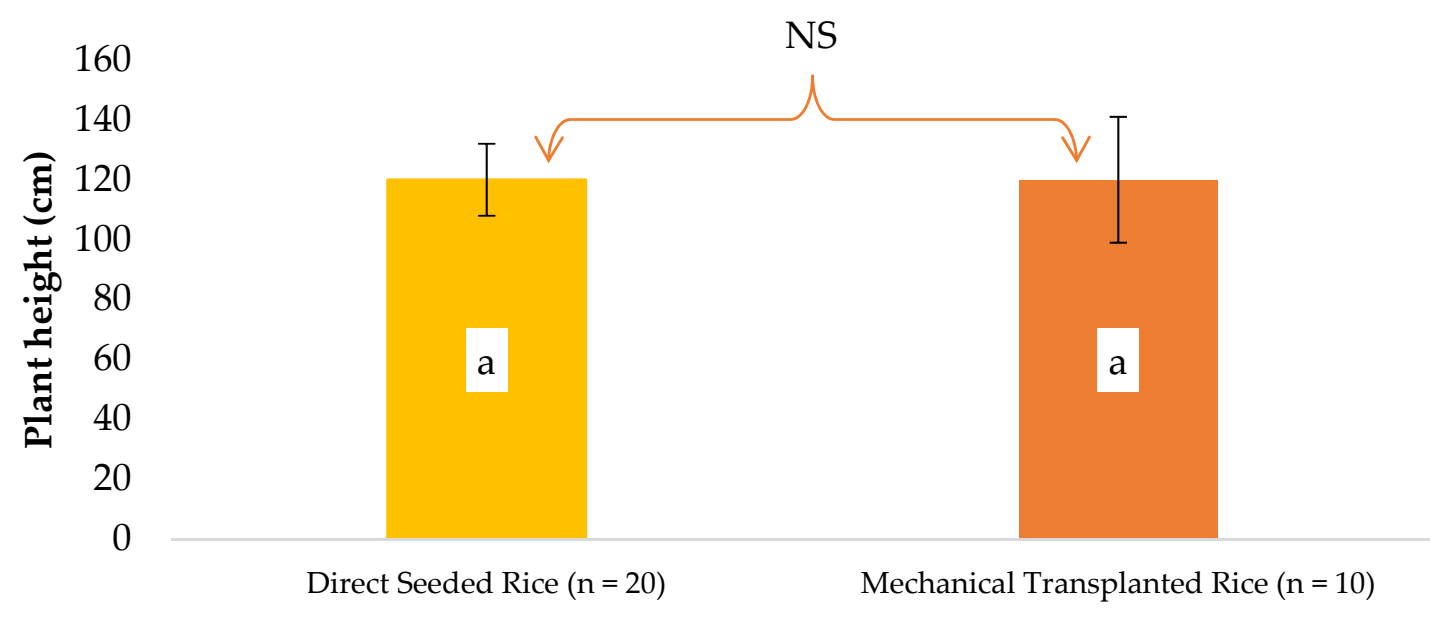

Crop establishment methods

(b)

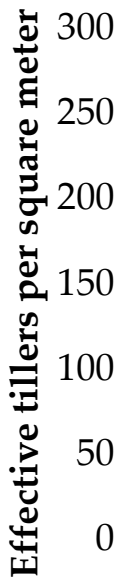

I

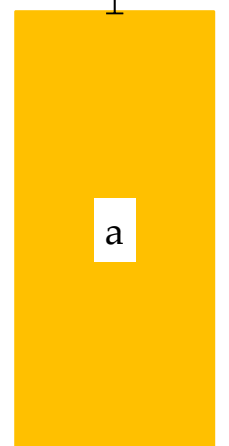

Direct Seeded Rice $(\mathrm{n}=20)$

Mechanical Transplanted Rice $(\mathrm{n}=10)$

\section{Crop establishment methods}

Figure 5. Cont. 
(c)

28

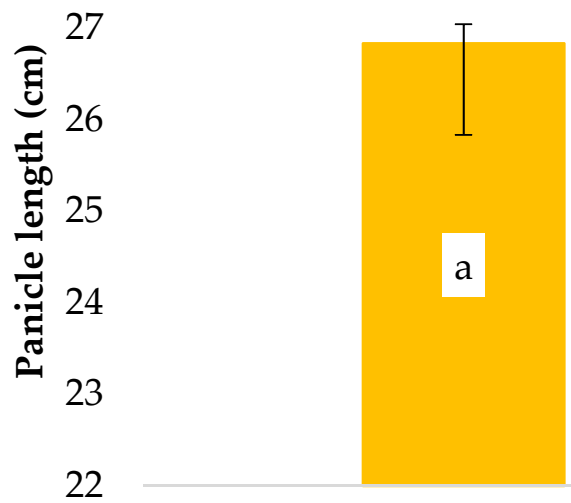

Direct Seeded Rice $(\mathrm{n}=20)$

Mechanical Transplanted Rice $(\mathrm{n}=10)$

\section{Crop establishment methods}

(d)
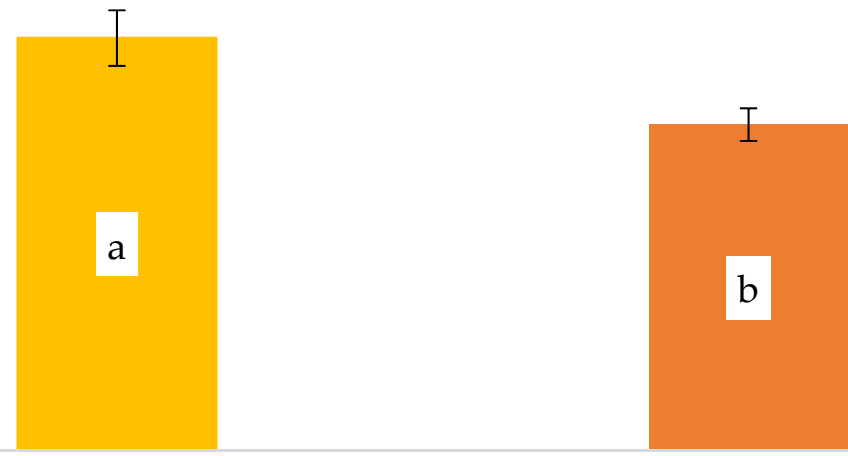

Direct Seeded Rice $(n=20)$

Mechanical Transplanted Rice $(\mathrm{n}=10)$

\section{Crop establishment methods}

Figure 5. Effect of crop establishment methods on (a) plant height at maturity; (b) effective tillers per square meter; (c) panicle length; and (d) the number of grains per panicle. Vertical bars for each column indicate standard deviation of the mean (for direct seeded rice $n=20$ and in mechanically transplanted rice $n=10$ ). Means of different land uses, followed by the different lowercase letters $(\mathrm{a}-\mathrm{b})$, are significantly different.

Data showed that the rice productivity significantly varied from 3.81 to $4.24 \mathrm{t} / \mathrm{ha}$. The significantly highest productivity $(4.24 \mathrm{t} / \mathrm{ha})$ was registered in the direct seeded rice and the lowest was reported ( $3.81 \mathrm{t} / \mathrm{ha})$ under the mechanifcal transplanted rice. Approximately $10 \%$ higher productivity was registered in the direct seeded rice compared with the mechanically transplanted rice (Figure $6 \mathrm{~b}$ and Table 1 ). 


\subsection{Crop Lodging Percentage and Rainfall Events}

The results show that a significant yield loss $(\sim 10 \%)$ was registered due to adverse climatic conditions. During the maturity of the rice crop, three major rainfalls (Figure 7a and Table 1) occurred: (i) $36.6 \mathrm{~mm}$ on 18 and 19 September 2021; (ii) $225.9 \mathrm{~mm}$ on 1 to 3 October 2021; and (iii) $39.6 \mathrm{~mm}$ on 8 October 2021. Data showed that higher crop lodgings of 40,80 , and $100 \%$ were registered in the mechanically transplanted rice and lower crop lodgings of 0,5 , and $25 \%$ were recorded under the direct seeded rice on 18 to 19 September 2021, 1 to 3 October 2021, and 8 October 2021, respectively (Figure 7b). In both cases, harvesting was performed by a combine harvester. It was also observed that, during the harvesting by the combine harvester, direct seeded rice performed very well, while the mechanically transplanted rice faced several problems (Figure 8a,b).

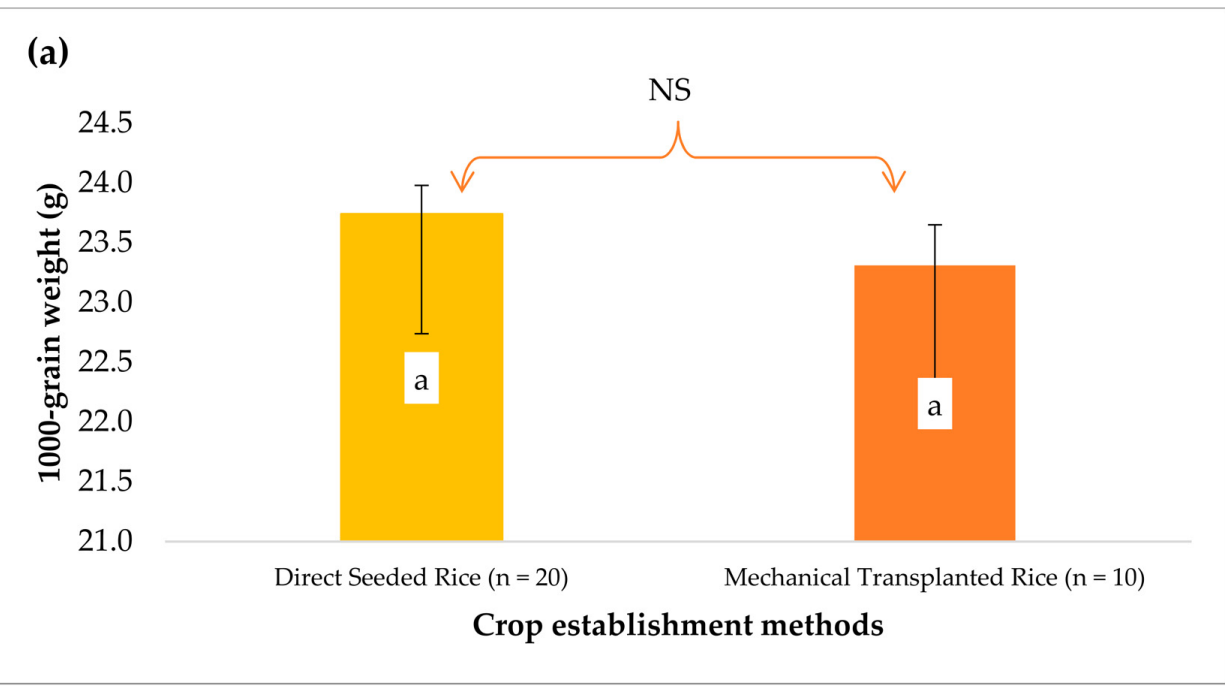

(b)

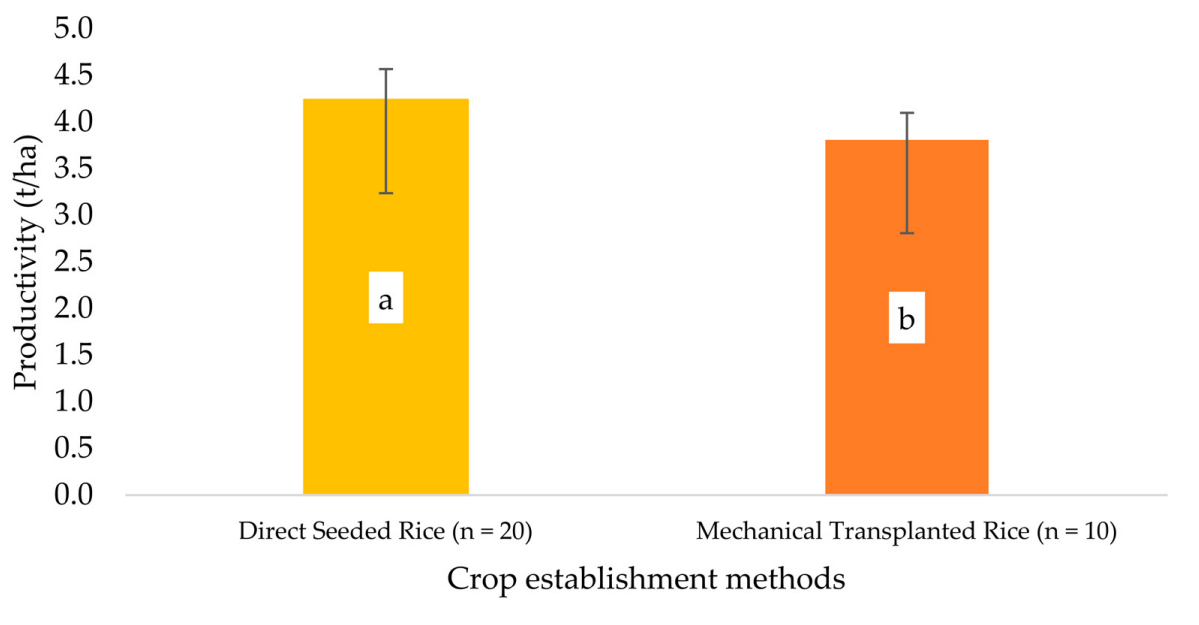

Figure 6. Effect of crop establishment methods on (a) 1000-grain weight and (b) rice productivity. Vertical bars for each column indicate standard deviation of the mean (for direct seeded rice $n=20$ and in mechanically transplanted rice $n=10$ ). Means of different land uses, followed by the different lowercase letters $(\mathrm{a}-\mathrm{b})$, are significantly different. 
Table 1. One-tail $t$-test of different growth and yield attributes and crop lodging of direct seeding and mechanically transplanted rice establishment methods.

\begin{tabular}{ccc}
\hline \multirow{2}{*}{ Attributes } & \multicolumn{2}{c}{ One-Tail $t$-Test } \\
\cline { 2 - 3 } & Growth attributes & $p$-Value \\
\hline Plant height & 1.73 & 0.50 \\
Effective tillers & 1.73 & $4.17274 \times 10^{-21}$ \\
Panicle length & 1.73 & 0.000504524 \\
\hline & Yield attributes & \\
\hline No of grains per panicle & 1.73 & $3.08195 \times 10^{-12}$ \\
1000 grain weight & 1.73 & 0.147245633 \\
Rice grain yield & 1.73 & 0.001877866 \\
\hline & Crop lodging & $1.17906 \times 10^{-14}$ \\
\hline 18 to 19 September 2021 & 1.73 & $3.46266 \times 10^{-19}$ \\
1 to 3 October 2021 & 1.73 & $5.4795 \times 10^{-25}$ \\
8 October 2021 & 1.73 &
\end{tabular}

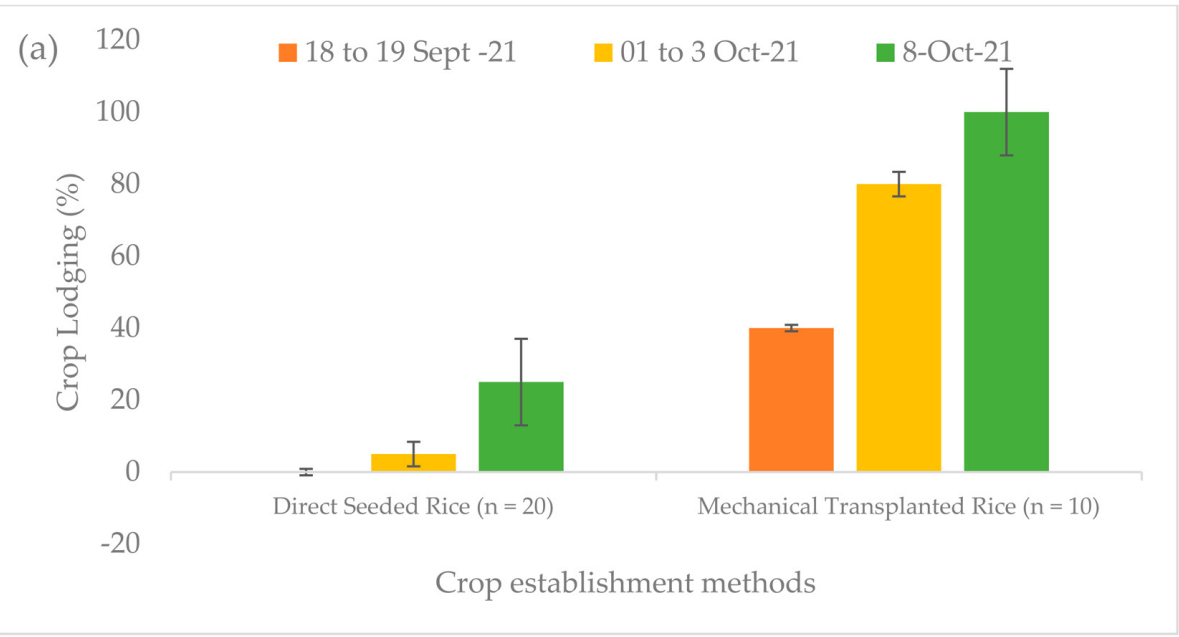

(b)

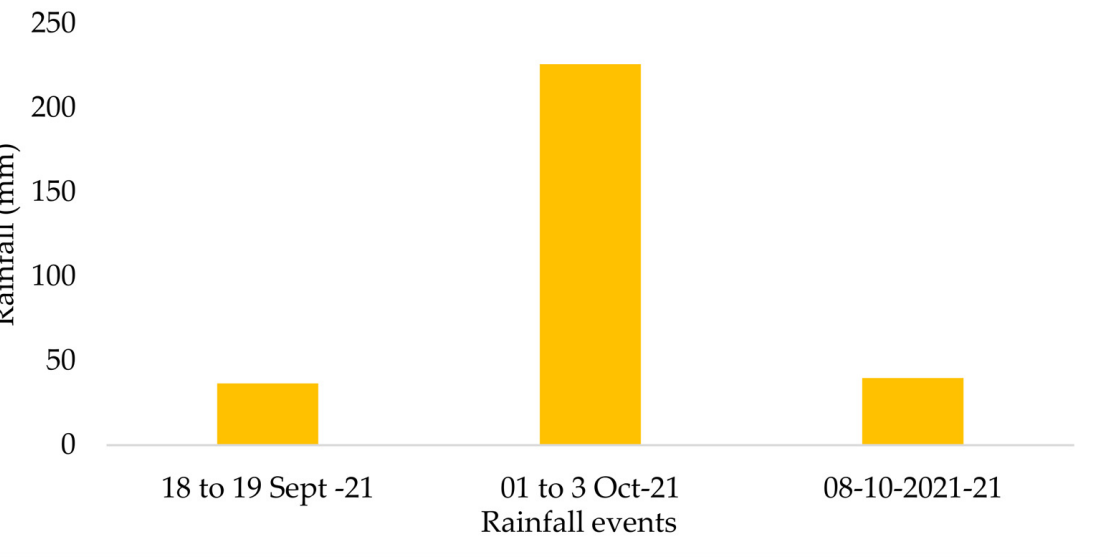

Figure 7. (a) Effect of crop establishment methods on crop lodging percentage. Vertical bars for each column indicate standard deviation of the mean (for direct seeded rice $n=20$ and in mechanically transplanted rice $n=10$ ) and (b) Cumulative rainfall events during the experimental season. 


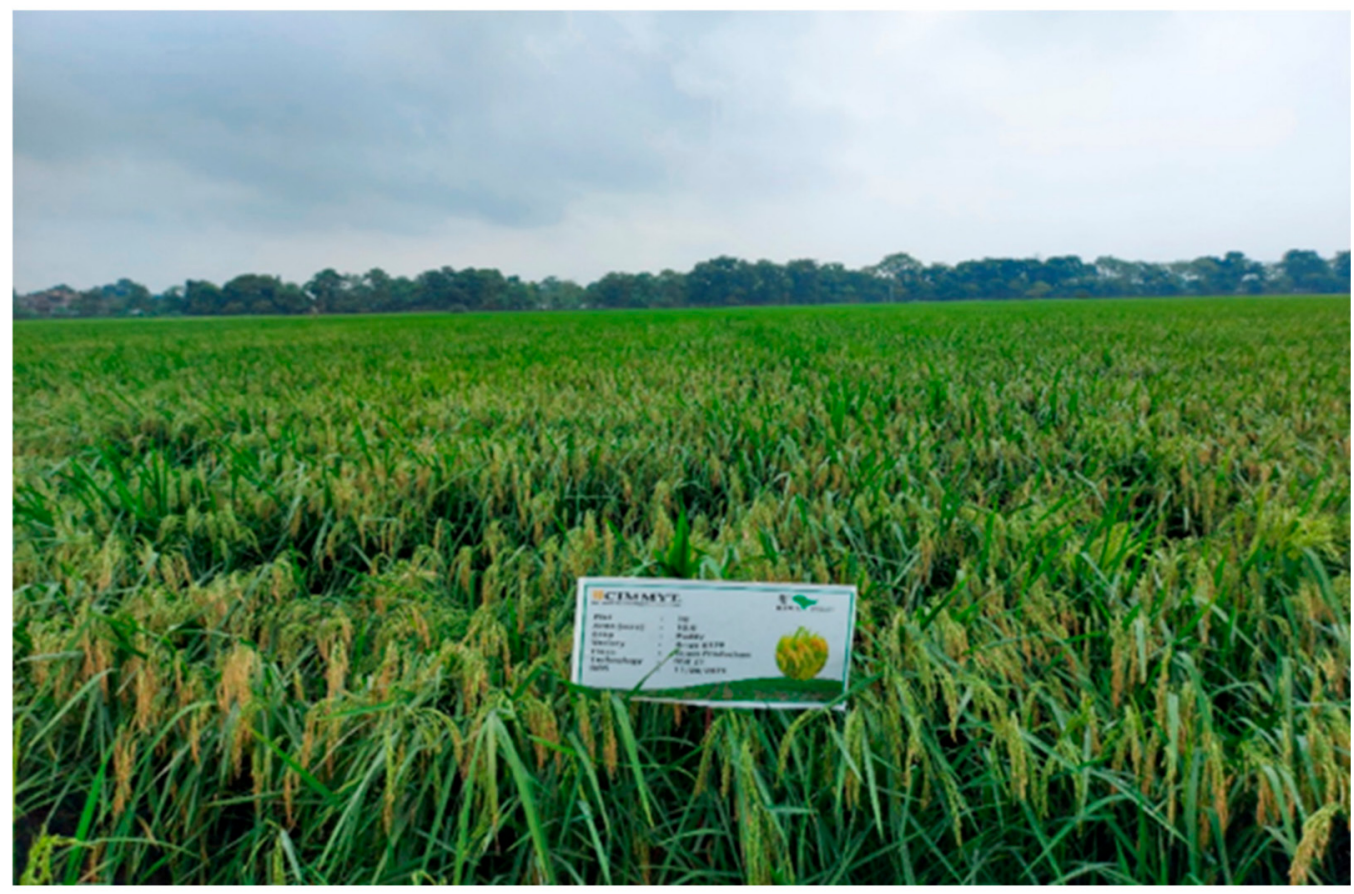

(a)

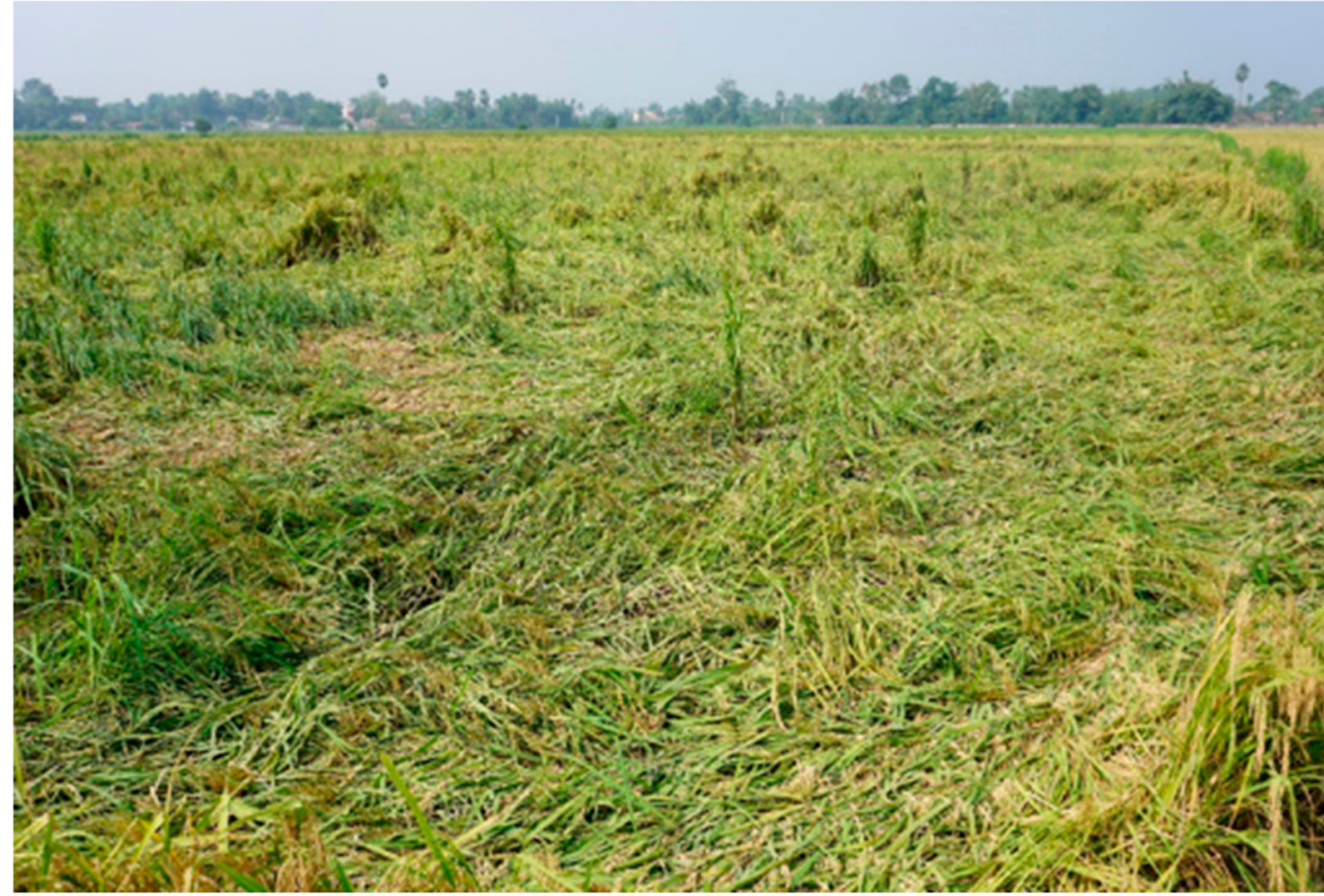

(b)

Figure 8. (a) Effect of adverse climatic conditions on the direct seeded rice crop. (b) Effect of adverse climatic conditions on the mechanically transplanted rice crop.

\section{Discussion}

Adverse climatic conditions have negatively affected agriculture production systems. The traditional puddled transplanted rice planting system is input intensive and degrades the soil system [22-25]. Irrespective of both crop establishment methods, direct seeded rice has a superior yield $(+10 \%)$ to mechanically transplanted rice. Due to intensive cultivation practices, puddling and submergence conditions during the cropping season increase environmental footprints [26-28]. The traditional puddled transplanted rice planting 
system is most popular among the farming community. However, in recent years, the DSR option is receiving more attention from the farming community as a more vital option for rice cultivation $[2,22,24]$. The DSR option is cost effective and environmentally friendly compared with the puddled transplanted rice system. Currently, farmers are shifting from the traditional puddled transplanted rice system to modern rice seeding methods (dry DSR and wet DSR) $[2,24,29,30]$. DSR allows crop seeding in dry conditions. Traditional methods, however, require intensive tillage, puddling, and submergence $(4-6 \mathrm{~cm})$ conditions. The DSR method has various benefits over the traditional puddled transplanted rice planting systems [31-33]. Meanwhile, the DSR crop will have a 10-14 day advantage in maturity in comparison with the traditional planting method [26,34,35].

We kept all crop management practices the same (variety, nutrient, water and weed management), except for the crop establishment method in both planting systems. We found higher rice productivity under the direct seeded system compared with the puddled transplanted system [36,37]. Characteristically, the DSR crop planting was timely, and transplant injury reduced the productivity $[38,39]$. The direct seeded crop has yield advantages over the traditional puddled transplanted rice planting methods $[2,33,39,40]$. The DSR crops have higher nutrients and are water and carbon efficient [2,41,42]. Additionally, puddled transplanted rice enhances greenhouse gas emissions. As reported by Pathak and others [43], in the districts of Punjab, direct seeding decreased the total global warming potential by approximately $33 \%$. Puddled transplanted rice crop growth and development suffered after puddling, which could lead to poor rooting due to compaction, and poor aggregation in the soil system $(17,36)$. The DSR method is cost, energy, and input efficient compared with traditional planting methods [40,44]. Crop lodging reduces the crop productivity [36,37,42-44].

\section{Conclusions and Future Perspectives of DSR Technology}

The data support the following conclusions:

- Direct seeded rice (DSR) has a $~ 10 \%$ yield advantage compared with mechanically transplanted rice.

- The results show that DSR technology has the potential to protect against up to $70 \%$ of crop lodging in adverse climatic conditions.

- DSR helps in advancing the planting dates of succeeding rabi crops, by at least 7-10 days, by saving the land preparation time.

Nowadays, direct seeding planting techniques in rice are becoming much more popular among the farming community due to cost, input, energy, and time efficiency and as an environmentally friendly, alternative solution to the traditional puddled transplanted rice planting method. Meanwhile, this technology has yield advantages compared with the traditional planting method (Figure 9).

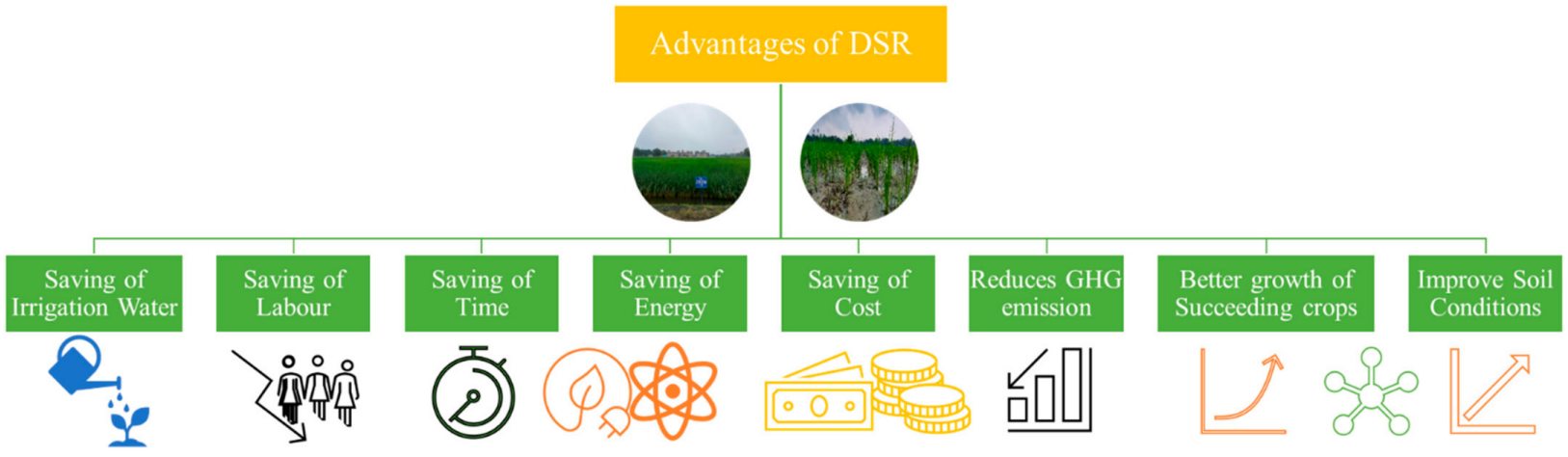

Figure 9. Advantages of adoption of DSR technology. 


\begin{abstract}
Author Contributions: All co-authors contributed to the conceptualization, planning and development of the article. All co-authors substantially contributed to the article. V.S.M. wrote the first draft of the manuscript with input from A.C.P. and V.S.J., M.K. and I.R.R. created the figures. V.S.M. and R.K.J. reviewed and finalized the manuscript. All authors have read and agreed to the published version of the manuscript.
\end{abstract}

Funding: This research was funded by the Government of Bihar (I7014.01), ICAR, and CGIAR.

Institutional Review Board Statement: Not applicable.

Informed Consent Statement: Not applicable.

Data Availability Statement: The data that support the findings of this study are available from the corresponding author upon reasonable request.

Acknowledgments: All technical staff of BISA that supported this trail are duly acknowledged. The financial support of the Climate Resilient Agriculture Program (I7014.01) funded by the Government of Bihar, ICAR and CGIAR research program. We are thankful to the field staff of BISA and the Climate Resilient Agriculture Program for support during the investigation.

Conflicts of Interest: The authors declare no conflict of interest.

\title{
References
}

1. Pittelkow, C.M.; Liang, X.; Linquist, B.A.; van Groenigen, K.J.; Lee, J.; Lundy, M.E.; van Gestel, N.; Six, J.; Venterea, R.T.; van Kessel, C. Productivity limits and potentials of the principles of conservation agriculture. Nature 2015, 517, 365-368. [CrossRef] [PubMed]

2. Jat, H.S.; Kumar, V.; Datta, A.; Choudhary, M.; Yadvinder-Singh; Kakraliya, S.K.; Poonia, T.; McDonald, A.J.; Jat, M.L.; Sharma, P.C. Designing profitable, resource use efficient and environmentally sound cereal based systems for the Western Indo-Gangetic plains. Sci. Rep. 2020, 10,1-16.

3. Lal, B.; Gautam, P.; Panda, B.; Tripathi, R.; Shahid, M.; Bihari, P.; Guru, P.; Singh, T.; Meena, R.; Nayak, A. Identification of energy and carbon efficient cropping system for ecological sustainability of rice fallow. Ecol. Indic. 2020, 115, 106431. [CrossRef]

4. Babu, S.; Mohapatra, K.; Das, A.; Yadav, G.S.; Tahasildar, M.; Singh, R.; Panwar, A.; Yadav, V.; Chandra, P. Designing energyefficient, economically sustainable and environmentally safe cropping system for the rainfed maize-fallow land of the Eastern Himalayas. Sci. Total Environ. 2020, 722, 137874. [CrossRef]

5. Jat, R.A.; Dungrani, R.A.; Arvadia, M.K.; Sahrawat, K.L. Diversification of rice (Oryza sativa L.)-based cropping systems for higher productivity, resource-use efficiency and economic returns in south Gujarat, India. Arch. Agron. Soil Sci. 2012, 58, 561-572. [CrossRef]

6. Kumar, R.; Mishra, J.S.; Mali, S.S.; Mondal, S.; Meena, R.S.; Lal, R.; Jha, B.K.; Naik, S.K.; Biswas, A.K.; Hans, H.; et al. Comprehensive environmental impact assessment for designing carbon-cum-energy efficient, cleaner and eco-friendly production system for rice-fallow agro-ecosystems of South Asia. J. Clean. Prod. 2021, 331, 129973. [CrossRef]

7. Zewde, N.; Gorham, R.D., Jr.; Dorado, A.; Morikis, D. Correction: Neglecting the fallow season can significantly underestimate annual methane emissions in Mediterranean rice fields. PLoS ONE 2018, 13, e0198081. [CrossRef]

8. Jat, S.; Parihar, C.; Singh, A.; Kumar, B.; Choudhary, M.; Nayak, H.; Parihar, M.; Parihar, N.; Meena, B. Energy auditing and carbon footprint under long-term conservation agriculture-based intensive maize systems with diverse inorganic nitrogen management options. Sci. Total Environ. 2019, 664, 659-668. [CrossRef]

9. Yadav, G.S.; Babu, S.; Das, A.; Mohapatra, K.; Singh, R.; Avasthe, R.; Roy, S. No-till and mulching enhance energy use efficiency and reduce carbon footprint of a direct-seeded upland rice production system. J. Clean. Prod. 2020, 271, 122700. [CrossRef]

10. Gathala, M.K.; Laing, A.M.; Tiwari, T.P.; Timsina, J.; Islam, S.; Bhattacharya, P.M.; Dhar, T.; Ghosh, A.; Sinha, A.K.; Chowdhury, A.K.; et al. Energy-efficient, sustainable crop production practices benefit smallholder farmers and the environment across three countries in the Eastern Gangetic Plains, South Asia. J. Clean. Prod. 2020, 246, 118982. [CrossRef]

11. Nandan, R.; Poonia, S.P.; Singh, S.S.; Nath, C.P.; Kumar, V.; Malik, R.K.; McDonald, A.; Hazra, K.K. Potential of conservation agriculture modules for energy conservation and sustainability of rice-based production systems of Indo-Gangetic Plain region. Environ. Sci. Pollut. Res. 2021, 28, 246-261. [CrossRef] [PubMed]

12. Bhatt, R.; Kukal, S.S.; A Busari, M.; Arora, S.; Yadav, M. Sustainability issues on rice-wheat cropping system. Int. Soil Water Conserv. Res. 2016, 4, 64-74. [CrossRef]

13. Bhatt, R.; Singh, P.; Hossain, A.; Timsina, J. Rice-wheat system in the northwest Indo-Gangetic plains of South Asia: Issues and technological interventions for increasing productivity and sustainability. Paddy Water Environ. 2021, 19, 1-21. [CrossRef]

14. Singh, P.; Singh, G.; Sodhi, G.P.S. Energy auditing and optimization approach for improving energy efficiency of rice cultivation in south-western Punjab, India. Energy 2019, 174, 269-279. [CrossRef]

15. Singh, A.K.; Das, B.; Mali, S.S.; Bhavana, P.; Shinde, R.; Bhatt, B.P. Intensification of rice-fallow cropping systems in the Eastern Plateau region of India: Diversifying cropping systems and climate risk mitigation. Clim. Dev. 2020, 12, 791-800. [CrossRef] 
16. Rao, K.K.; Samal, S.K.; Poonia, S.P.; Kumar, R.; Mishra, J.S.; Bhatt, B.P.; Dwivedi, S.K.; Mondal, S.; Choubey, A.K.; Kumar, S.; et al. Conservation agriculture improves soil physical properties and crop productivity: A long-term study in middle Indo-Gangetic Plains of India. Soil Res. 2021. [CrossRef]

17. Kumar, V.; Ladha, J. Direct seeding of rice: Recent developments and future research needs. Adv. Agron. 2011, 111, $297-413$.

18. Quilloy, F.A.; Labaco, B.; Dixit, S.; Casal, C. Crop Establishment in Direct-Seeded Rice: Traits, Physiology, and Genetics. In Rice Improvement; Springer Science and Business Media LLC: Cham, Switzerland, 2021; pp. 171-202.

19. Sandhu, N.; Yadav, S.; Catolos, M.; Cruz, M.T.S.; Kumar, A. Developing Climate-Resilient, Direct-Seeded, Adapted MultipleStress-Tolerant Rice Applying Genomics-Assisted Breeding. Front. Plant Sci. 2021, 12, 637488. [CrossRef]

20. Samal, S.; Rao, K.K.; Poonia, S.; Kumar, R.; Mishra, J.; Prakash, V.; Mondal, S.; Dwivedi, S.; Bhatt, B.; Naik, S.K.; et al. Evaluation of long-term conservation agriculture and crop intensification in rice-wheat rotation of Indo-Gangetic Plains of South Asia: Carbon dynamics and productivity. Eur. J. Agron. 2017, 90, 198-208. [CrossRef]

21. Farooq, M.; Wahid, A.; Lee, D.-J.; Ito, O.; Siddique, K.H.M. Advances in drought resistance of rice. Crit. Rev. Plant Sci. 2009, 28, 199-217. [CrossRef]

22. Farooq, M.; Basra, S.M.A.; Ahmad, N.; Murtaza, G. Enhancing the performance of transplanted coarse rice by seed priming. Paddy Water Environ. 2009, 7, 55-63. [CrossRef]

23. Pandey, S.; Velasco, L.E. Economics of alternative rice establishment methods in Asia: A strategic analysis. In Social Sciences Division Discussion Paper; International Rice Research Institute: Los Baños, Philippines, 1999.

24. Pandey, S.; Velasco, L. Economics of direct seeding in Asia: Patterns of adoption and research priorities. In Direct Seeding: Research Strategies and Opportunities; Pandey, S., Mortimer, M., Wade, L., Tuong, T.P., Lopes, K., Hardy, B., Eds.; International Rice Research Institute: Los Baños, Philippines, 2002.

25. Pandey, S.; Velasco, L. Trends in crop establishment methods in Asia and research issues. 2005, Rice is Life: Scientific Perspectives for the 21st Century. In Proceedings of the World Rice Research Conference, Tsukuba, Japan, 4-7 November 2004.

26. Farooq, M.; Siddique, K.; Rehman, H.; Aziz, T.; Lee, D.-J.; Wahid, A. Rice direct seeding: Experiences, challenges and opportunities. Soil Tillage Res. 2011, 111, 87-98. [CrossRef]

27. Raj, S.K.; Syriac, E.K. Weed management in direct seeded rice: A review. Agric. Rev. 2017, 38, 41-50. [CrossRef]

28. Singh, Y.; Singh, G.; Johnson, D.; Mortimer, M. Changing from transplanted rice to direct seeding in the rice-wheat cropping system in India. In Rice is Life: Scientific Perspectives for the 21st Century. Proceedings of the World Rice Research Conference, Tsukuba, Japan, 4-7 November 2004; International Rice Research Institute: Tsukuba, Japan, 2005; pp. 198-201.

29. Singh, S.; Bhushan, L.; Ladha, S.K. Evaluation of new crop establishment/tillage techniques in rice-wheat system. In Proceedings of the Agenda Notes, 13th Regional Technical Coordination Committee Meeting, Dhaka, Bangladesh, 6-8 February $2004 ;$ p. 12.

30. Singh, V.P.; Singh, G.; Singh, S.P.; Kumar, A.; Singh, Y.; Johnson, D.E.; Mortimer, M. Effect of rice wheat establishment methods and weed management in irrigated rice-Wheat production system. In Workshop on "Direct Seeded Rice in the Rice-Wheat System of the Indo-Gangetic Plains, 1 February to 2 February 2005, G.B.; Pant University of Agriculture and Technology: Pantnagar, India, 2005; p. 12.

31. Balasubramanian, V.; Hill, J.E. Direct seeding of rice in Asia: Emerging issues and strategic research needs for the 21st century. In Direct Seeding: Research Strategies and Opportunities; Pandey, S., Mortimer, M., Wade, L., Tuong, T.P., Lopez, K., Hardy, B., Eds.; International Rice Research Institute: Los Baños, Philippines, 2002; pp. 15-42.

32. Balasubramanian, V.; Ladha, J.K.; Gupta, R.K.; Naresh, R.K.; Mehla, R.S.; Yadvinder-Singh, B.-S. Technology options for rice in the rice-wheat system in South Asia. In Improving the Productivity and Sustainability of Rice-Wheat Systems: Issues and Impacts; Ladha, J.K., Hill, J.E., Duxbury, J.M., Gupta, R.K., Buresh, R.J., Eds.; ASA Special Publication: Madison, WI, USA, 2003.

33. Tuong, T.P.; Pablico, P.P.; Yamauchi, M.; Confesor, R.; Moody, K. Increasing water productivity and weed suppression of wet seeded rice: Effect of water management and rice genotypes. Exp. Agric. 2000, 36, 71-89. [CrossRef]

34. Gupta, R.K.; Ladha, J.K.; Singh, S.; Singh, R.J.; Jat, M.L.; Saharawat, Y.; Singh, V.P.; Singh, S.S.; Sah, G.; Gill, M.S.; et al. Production technology for direct seeded rice. In Rice Wheat Consortium Technical Bulletin 8; ICAR-Agricultural Technology Application Research Institute: New Delhi, India, 2006.

35. Ladha, J.K.; Pathak, H.; Padre, A.T.; Dawe, D.; Gupta, R.K. Productivity trends in intensive rice-wheat cropping systems in Asia. In Improving the Productivity and Sustainability of Rice-Wheat Systems: Issues and Impacts; JASA Special Publication No. 65.; Ladha, K., Hill, J.E., Buresh, R.J., Duxbury, J., Gupta, R.K., Eds.; ASA, CSSA and SSSA: Madison, WI, USA, 2003; pp. 45-76.

36. Gathala, M.K.; Ladha, J.K.; Kumar, V.; Saharawat, Y.S.; Kumar, V.; Sharma, P.K.; Sharma, S.; Pathak, H. Tillage and Crop Establishment Affects Sustainability of South Asian Rice-Wheat System. Agron. J. 2011, 103, 961-971. [CrossRef]

37. Jat, R.K.; Sapkota, T.; Singh, R.G.; Jat, M.; Kumar, M.; Gupta, R.K. Seven years of conservation agriculture in a rice-wheat rotation of Eastern Gangetic Plains of South Asia: Yield trends and economic profitability. Field Crop. Res. 2014, 164, 199-210. [CrossRef]

38. Fanish, S.A. Enhancing resource use efficiency (RUE) under direct seeded rice (DSR) system: A review. Am. Eurasian J. Agric. Env. Sci. 2016, 16, 1534-1544.

39. Akhgari, H.; Kaviani, B. Assessment of direct seeded and transplanting methods of rice cultivars in the northern part of Iran. Afr. J. Agric. Res. 2011, 6, 6492-6498.

40. Gangwar, K.S.; Tomar, O.K.; Pandey, D.K. Productivity and economics of transplanted and direct-seeded rice (Oryza sativa) based cropping systems in Indo-Gangetic plains. Indian J. Agric. Sci. 2008, 78, 655-658. 
41. Setter, T.; Laureles, E.; Mazaredo, A. Lodging reduces yield of rice by self-shading and reductions in canopy photosynthesis. Field Crop. Res. 1997, 49, 95-106. [CrossRef]

42. Kaur, J.; Singh, A. Direct Seeded Rice: Prospects, Problems/Constraints and Researchable Issues in India. Curr. Agric. Res. J. 2017, 5, 13-32. [CrossRef]

43. Pathak, H.; Sankhyan, S.; Dubey, D.S.; Bhatia, A.; Jain, N. Dry direct-seeding of rice for mitigating greenhouse gas emission: Field experimentation and simulation. Paddy Water Environ. 2013, 11, 593-601. [CrossRef]

44. Ogata, T.; Matsue, Y. Studies on direct sowing culture of rice in northern Kyushu. Jpn. J. Crop Sci. 1996, 65, 87-92. [CrossRef] 